(Final Version)

\title{
The Multinational Enterprise as a Source of International Knowledge Flows: Direct Evidence from Italy
}

\author{
Nigel Driffield ${ }^{1}$, James H Love ${ }^{*^{1}}$ and Stefano Menghinello ${ }^{1,2}$ \\ ${ }^{1}$ Economics and Strategy Group \\ ${ }^{2}$ Istituto nazionale di statistica (ISTAT) \\ Aston Business school \\ Aston University \\ Birmingham B4 7ET \\ UK \\ Direzione centrale statistiche economiche strutturali \\ Sede di Via Anagnina \\ Via Cesare Balbo, 16 \\ 00100 Rome \\ Italy \\ n.l.driffield@aston.ac.uk \\ menghine@istat.it \\ j.h.love@aston.ac.uk
}

\begin{abstract}
This paper examines the determinants of technology transfer between parent firms and their international affiliates, and of knowledge spillovers from those affiliates to host country firms. Using a unique dataset of foreign MNE affiliates based in Italy, we find that affiliate investment in $\mathrm{R} \& \mathrm{D}$ and investment in capital-embodied technology plays a significant role in determining the nature of intra-firm technology flows. However, the basis for any spillovers arising from MNE affiliates does not originate from codified knowledge associated with $R \& D$, but rather from the productivity of the affiliate.

* Corresponding author (j.h.love@aston.ac.uk)
\end{abstract}

Keywords: intra-firm technology transfer, knowledge spillovers, technology sourcing. 


\section{Introduction}

The purpose of this paper is to examine the role of the multinational enterprise (MNE) in international technology and knowledge transfer. The fundamental theories of international technology transfer within the firm are rooted in an implicit model of knowledge transfer from a technologically advanced home base to a foreign affiliate. In turn, much of the empirical work in this area has then inferred the existence of this intra-firm transfer by seeking to measure the apparent productivity growth in the host economy associated with foreign direct investment ${ }^{1}$.

The implicit model on which this is based assumes both that foreign subsidiaries in a given location are able to source technology internationally, either from their parent company or from elsewhere, and that the affiliate transfers technology, either by accident or design, to local enterprises. In practice there is no guarantee that either condition will be fulfilled. First, not all multinationals employ frontier technology, and not all affiliates of those that do automatically have access to the leading technology of their parent company. Second, and notwithstanding the possibility of inadvertent leakage, multinational enterprises frequently go to considerable lengths to internalise their knowledge and prevent or control its transfer to third parties (Veugelers and Cassiman 2004).

However, another strand of research suggests that the crucial role of foreign affiliates in technology transfer has been underestimated. This literature stresses the role of the affiliate in technology production rather than merely adaptation, which may result in efficiency-enhancing spillovers deriving directly from the activities of affiliates, rather than seeing them merely as conduits to knowledge and technology developed elsewhere (Bell and Marin 2004; Marin and Bell 2006).

This suggests that empirical research should neither take for granted the transfer of technology from MNEs to their affiliates, nor should it ignore the role of affiiates both in intra-firm technology transfer and in generating spillovers. Here we employ a direct method of evaluating both the presence of technology transfer within the MNE, and its effects on domestic enterprises. We examine the determinants of these technology transfers and spillovers, paying particular attention to the roles of $R \& D$, knowledge capital and affiliate performance.

\section{Foreign Affiliates, Knowledge Transfer and Spillovers}

The nature of knowledge flows between parents and affiliates and the subsequent spillovers to domestic firms can be categorised in two simple 2x2 matrices, which link the nature of knowledge transfer to concepts familiar from the international business literature. Figure 1 shows the four possible types of knowledge flows which may occur between an MNE and its affiliates. Quadrants 1 and 4 represent cases where there are either two-way transfers or no knowledge transfers between parent and affiliate. Quadrants 2 and 3 represent one way transfers, either from parent to affiliate or affiliate to parent. The first of these (quadrant 2) can be thought of as standard 'knowledge exploiting' behaviour within Dunning's OLI framework, in which an

\footnotetext{
${ }^{1}$ For recent discussions of this literature see Haskel et al (2007) or Wei and Liu (2006).
} 
MNE exploits its superior knowledge in a host country by transferring the knowledge to its foreign affiliate. Quadrant 3 represents the situation where knowledge flows only from affiliate to parent ('knowledge sourcing'), because the affiliate is a research establishment set up for that purpose, or because it is a 'listening post' designed to source knowledge from the local economy.

(Figures 1 and 2 about here)

The second matrix (Figure 2) relates the nature of intra-group knowledge transfer to knowledge transfer into the host economy. The top row describes knowledge flows from the parent company to its foreign affiliate, and this either does (quadrant 1) or does not (quadrant 2) result in spillovers to the local economy. In the bottom row there are no knowledge transfers from the MNE parent. Quadrant 3 represents a position in which, despite the lack of knowledge from the parent, the affiliate nevertheless supplies knowledge spillovers to the domestic economy, presumably from knowledge generated internally. The final quadrant (4) represents a position of neither intra-group knowledge flows nor subsequent spillovers.

We now outline theoretical determinants of these knowledge transfers and spillovers, paying particular attention to the roles of $R \& D$, knowledge capital and affiliate performance in determining the nature and direction of knowledge flows.

\section{Determinants of technology transfer within the firm (Figure 1)}

Recent conceptual and empirical analysis suggests that the nature of the knowledge flows between parent and affiliate depend on the strategic position of the subsidiary and its relative performance (Andersson et al 2001, 2005, 2007). This literature highlights the importance both of the technological capacity and of the success of the subsidiary in explaining subsidiary-parent technology transfer. Our focus is on technological development, which is more likely to be related to factors such as $R \& D$, intangible assets and exporting intensity, rather than more obvious measures of performance such as financial performance.

R\&D intensity of the affiliate is an indicator not only of subsidiary performance, but also of how the subsidiary is viewed strategically by the parent. Cohen and Levinthal (1989) stress that R\&D capacity has two dimensions: it contributes directly to innovation and knowledge creation, and also forms the basis for absorptive capacity, permitting technology and knowledge to be absorbed from elsewhere. The absorptive capacity element of $R \& D$ provides the subsidiary with the capacity to absorb technology from the parent, and elsewhere within the MNE. However, this capacity can also be used to source and channel technology from host economies. The literature on the internationalisation of $R \& D$ suggests that there is a growing willingness to locate affiliate $R \& D$ facilities close to leading centres of research and innovation specifically with a view to absorbing learning spillovers from geographical proximity to such sites (Serapio and Dalton, 1999; Ito and Wakasugi 2007). Here, affiliate-level R\&D provides the basis for technology sourcing from the host economy and subsequent transfer back to the parent. Thus the absorptive capacity element of $\mathrm{R} \& \mathrm{D}$ provides the capacity for two-way flows of technology, both from parent to affiliate but also for transfers from affiliate to parent via technology sourcing from host economy (quadrant 1 ). 
As described by Cohen and Levinthal (1989), R\&D also has a strong direct effect on innovation and knowledge creation. In the context of the MNE, affiliate R\&D and knowledge assets thus provide not only the capacity to absorb technology from the parent MNE and from the host economy, but also potentially the basis for affiliate's self-generated technology flows back to the parent even where technology flows from the parent are limited or absent (quadrant 3). Bell and Marin (2004) and Marin and Bell (2006) illustrate not only that such an effect may exist, but that it arises not merely from the R\&D capacity of affiliates, but also from their investment in capitalembodied technology, mainly through intangible knowledge assets. This discussion of the dual role of $\mathrm{R} \& \mathrm{D}$ and knowledge assets leads to the first hypothesis:

H1: Affiliate investment in R\&D and knowledge capital is positively associated with two-way technology flows and with affiliate-parent technology flows.

While R\&D is an important dimension of technology flows from affiliates to parents, by contrast, R\&D-intensive and knowledge capital-intensive subsidiaries are relatively unlikely to be the recipients of one-way technology flows from parent companies (quadrant 2). An MNE is unlikely to invest heavily in the R\&D capacity of an affiliate merely to channel technology from parent to affiliate. There may, of course, be some need for adaptation, but this does not normally require a high level of $\mathrm{R} \& \mathrm{D}$ intensity. This is especially true of a relatively advanced host economy such as Italy, in which there is typically relatively little need for technology adaptation before parental technology can be applied to the local market. As a result, the standard 'technology exploiting' transfers (quadrant 2) are more likely to occur with respect to relatively less-R\&D and knowledge-capital intensive subsidiaries. This leads to the second hypothesis:

H2: Affiliate investment in $R \& D$ and knowledge capital is negatively related to oneway parent-affiliate technology flows.

The role of the affiliate with respect to exports is also important. There is strong evidence that firms entering export markets must first develop the capabilities required to compete in highly competitive international markets ${ }^{2}$. In the case of MNE affiliates, even where an affiliate is initially a platform for exports built on technology derived from the parent, the affiliate may develop capabilities derived from exporting which can then serve as a possible source of knowledge flows back to the parent. Support for this hypothesis comes from Ito and Wakasugi (2007), who find that a high propensity to export is associated with a greater incidence of technology sourcing R\&D among Japanese overseas subsidiaries. We therefore expect export intensity to be positively related to knowledge-sourcing behaviour.

H3: Export intensity is positively related to affiliate-parent technology flows,

\section{Determinants of spillovers (Figure 2)}

The extensive literature on spillovers from FDI says surprisingly little about the mechanisms by which spillovers occur. The main theoretical basis for the existence of spillovers is the OLI theory, linking the MNE's ownership advantage to the theory of

\footnotetext{
${ }^{2}$ For a review of this voluminous literature see Wagner (2007)
} 
technology transfer from inward investors to domestic firms through rather vaguely specified mechanisms, such as demonstration or competition effects (Caves 1996) as well as pure technology transfer effects. Even review papers such as Blomstrom and Kokko (1998) highlight only 'possibilities' such as direct licensing agreements, supplier networks or subcontracting. Many explanations are simply grouped together using the phrase 'indirect transfer as knowledge becomes public', though this also assumes a distinction between technology transfer and other forms of knowledge such as management or working practices. These issues are discussed in detail in Driffield and Love (2007).

Empirical analysis within the OLI framework has generally tested for technology transfer by inference, largely based on the extent to which the presence of foreign investors in a given location generates productivity growth in the domestic sector (Haskel et al 2007; Wei and Liu 2006). While informative, this is an indirect test of the theory of international technology transfer. Such studies provide no direct means of establishing whether the technology which forms the basis for productivity spillovers is transferred from the parent or generated by the affiliate in a foreign location. Nor, crucially, do such indirect tests provide a clear indication of what constitutes the source of such spillovers. Finally, this form of analysis provides no insight into the mechanisms by which parent-affiliate or affiliate-host technology transfer may occur.

A strand of this literature deals specifically with the capacity of affiliates themselves to generate spillovers directly, rather than as a result of parental knowledge transfer. Bell and Marin (2004) argue that this depends crucially on the local technological activities of affiliates, and especially the roles of R\&D and investment in capitalembodied technology. R\&D at the subsidiary level provides the capacity to generate knowledge directly which can then spill over to domestic firms, even in the absence of technology flows from the parent (i.e. quadrant 3).

However, R\&D or knowledge capital per se is unlikely to be linked directly to technology transfer to the domestic sector. In terms of spillover generation, R\&D is indicative of technological development, but it is also indicative of private knowledge, which the MNE (and its affiliate) may seek to prevent leaking out. Productivity, however, is indicative of the efficient use of knowledge, and its non-proprietary nature makes it harder to protect from leakage. As a result, productive affiliates are more likely to generate spillovers, regardless of the underlying source of that productivity, and there is evidence to that effect (Oulton 1997; Driffield 2001).

This discussion leads to the following joint hypotheses:

H4a: Affiliate productivity is positively associated with spillovers to the domestic sector, originating both from parental technology flows and from the affiliate's own technology.

H4b: Affiliate productivity is more strongly associated with spillovers than is affiliate R\&D.

Note that both hypotheses $4 \mathrm{a}$ and $4 \mathrm{~b}$ hold in principle regardless of the ultimate source of the technology i.e. whether they derive from the MNE or from the 
technological activity of the affiliate itself. This is essentially an empirical issue: the advantage of the classification in Figure 2 and the empirical analysis below is that it distinguishes clearly between the determinants of spillovers arising from technology transfer from the parent MNE (quadrant 1) and those arising directly from technology produced by the affiliate itself (quadrant 3). This therefore provides a more direct means of establishing whether the technology which forms the basis for productivity spillovers is transferred from the parent or generated by the affiliate in a foreign location.

\section{Data and Method}

The empirical part of this paper exploits a unique dataset at the firm level produced by ISTAT (the Italian National Statistical Institute) for a large sample of foreign affiliates resident in Italy. This was part of an official survey of over 6,500 foreign affiliates within the framework of an EU Regulation, which had a census nature for large and medium size companies (50+ employees) and a random nature (stratified by industry) for small businesses ${ }^{3}$. The questionnaire was addressed to top management positions (e.g. CEO, chief accounting officer) in the company; reply was mandatory under Italian law. The sample considered here focuses on manufacturing and hightechnology services for a total of 921 companies ${ }^{4}$. Table 1 shows the distribution of firms in the sample by technology and knowledge-intensive sectors.

The dataset combines standard quantitative data with unique information on Italian resident foreign affiliates (Table 2). These are derived by linking the official survey on foreign affiliates with multiple official surveys, including those based on company accounts, foreign trade in goods, and $\mathrm{R} \& \mathrm{D}$. All variables originate from official surveys whose samples were drawn from the Italian business register set up and maintained by ISTAT, and are collected with respect to the same reference year and linked through the business register identification code. This guarantees the full consistency of the results.

(Tables 1 and 2 about here)

Data on technology transfer were collected by ISTAT in a special section of the questionnaire of the Italian survey on resident enterprises under foreign control (see

\footnotetext{
${ }^{3}$ Micro-data used in this paper refer to the Official Survey on foreign affiliates in Italy, carried out by the Italian National Statistical Institute (ISTAT) in 2005-2006. Qualitative questions on knowledge transfer were introduced following OECD recommendations to increase the stock of available information on MNE behaviour. Aggregated figures were disseminated by ISTAT in February 2007, while micro-data were made available for research purposes shortly after. The dataset used in this paper can be accessed upon request at the ADELE laboratory located in the headquarters of ISTAT in Rome.

${ }^{4}$ The reasons for concentrating this study on manufacturing and HTKIS companies are twofold. First, the focus of the research is on industries with a clear relevance of technology as a driver of the industry, this is clearly beyond the scope of most traditional service industries (dominated by e.g. retailing and wholesaling), where international intra-firm technological transfer is not a significant feature. Second, some firm level performance indicators, such as TFP and profitability, could not be calculated with respect to most of the service industries, partly because of data constraints and also because TFP is not a particularly meaningful indicator for most traditional service sectors.
} 
Annex for details). This was part of a study promoted by the OECD on the role played by foreign MNEs for the domestic economy. In particular, two questions were explicitly designed to focus on knowledge transfers between the foreign affiliates and their parent companies, as well as on the potential benefits for other resident firms indirectly generated by the activity of foreign affiliates (i.e. spillover effects). These discrete variables convey evaluations made by managers working in foreign affiliates.

The first question refers to international technology transfer between the parent company and their Italian affiliates (Annex question 5.1). This question considers both the nature and the direction of the scientific or technical knowledge transfer ${ }^{5}$. The direction of flow distinguishes between the flow from the Italian affiliate to the parent (affiliate-parent transfer), and the opposite (parent-affiliate transfer). The second question seeks to determine indirect and externality effects generated by foreign affiliates on the Italian economy. The key question here asks the affiliate whether its presence has resulted in the diffusion of new competences and knowledge among other resident firms (Annex question 5.2c). As with the first question, responses are categorical in nature, with no information on the scale, intensity or significance of knowledge transfer.

A multinomial logit model (MNLM) is used to link different patterns of MNE knowledge transfer and diffusion to a set of explanatory variables. Within this analytical framework, each of the four patterns of MNE behaviour identified in Figures 1 and 2 identifies a specific category of a nominal outcome which is compared, in terms of probability, to the other three categories. These relative probabilities, called odds ratios, are then expressed as a non-linear function of the explanatory variables.

The independent variables in the MNLM estimation comprise a series of continuous and discrete variables which the conceptual and empirical literature suggests are most likely to distinguish between the patterns of affiliate behaviour in the quadrants of Figures 1 and 2. In particular, we pay attention to R\&D intensity, knowledge capital, export propensity, and affiliate performance in terms of both total factor productivity (TFP) and profitability ${ }^{6}$. Finally we allow for size of affiliate (by employment) and its square. We have no specific priors with respect to these variables, and regard them as conditioning variables along with the sectoral industry dummies outlined earlier. Parent country dummy variables are also included. A correlation matrix for the key dependent and independent variables is shown in Table 3.

(Table 3 about here)

\footnotetext{
${ }^{5}$ Scientific and technological knowledge can be embedded in material goods, formally incorporated in patents, licences or software, or stem from $R \& D$, innovation or project activities. This is distinct from managerial competencies, including new managerial procedures or strategies. Note that the question allows for transfer to/from the Italian affiliate from/to any part of the MNE group, not merely headquarters.

${ }^{6}$ TFP is calculated as the Solow's residual from a Cobb-Douglas production function specification, while profitability is given by gross operating margin (value added minus wage costs) as a share of turnover.
} 


\section{Results}

\section{a) Intra-group technology flows}

Table 4 shows the results of the MNLM estimations for intra-group technology transfer. In each case the coefficients of the model are expressed as log-odds ratios, relative to the base category of Figure 1 (quadrant 4 - no knowledge transfer).

(Table 4 about here)

In terms of technology transfers, the most notable result is a very strong effect of R\&D intensity. As expected, R\&D intensity is positively associated with the likelihood of an affiliate engaging in both technology sourcing and two-way technology transfer, and negatively with the likelihood of its simply being a vehicle for technology exploitation via one-way transfers from the parent. Capital intensity is also positively associated with technology sourcing behaviour, but this effect is restricted to intangible assets, suggesting the importance of technology flows from affiliates to parents which are not embodied in physical assets. $\mathrm{H} 1$ and $\mathrm{H} 2$ are therefore supported.

The more productive is a subsidiary, the less likely it is to be a source of technology sourcing activity. Taken together with the R\&D results, this suggests that technology flows from affiliates to parents are based on the R\&D and knowledge capital of the affiliates, not their productivity. This affords an interesting contrast with the spillover results (see below).

Finally, export intensity is strongly positively associated with technology sourcing behaviour. This supports H3, suggesting that export intensive plants are able to develop capabilities which in turn are able to develop into a source of technology flows back to the parent enterprise. The fact that export intensity is also negatively correlated with parent-affiliate technology exploiting flows suggests that MNE affiliates in Italy do not derive their export capacity from technology transfer from their parent companies.

There are also some marked differences in technology transfer behaviour among affiliates of different nationalities. Specifically, Japanese affiliates are extremely unlikely to exhibit affiliate-parent technology sourcing behaviour. If Japanese technology sourcing occurs in Italy, it occurs in the form of two-way technology flows, which is more common among Japanese affiliates than those from the US or EU. Finally, medium-low technology manufacturing affiliates are much more likely to exhibit one-way technology sourcing behaviour.

\section{b) Affiliate-domestic knowledge transfer}

Table 5 shows the results of the MNLM estimations relating intra-group technology transfer to spillovers. The base category here is quadrant 4 of Figure 2 (no knowledge transfer or spillovers).

(Table 5 about here) 
The key findings relate to R\&D and productivity. First, R\&D intensity in the affiliate is negatively related to spillovers arising from parent company knowledge flows, while affiliate productivity is positively related. By contrast, neither affiliate R\&D nor productivity is associated with affiliate-only spillovers (relative to the base case of quadrant 4). There is therefore partial support for $\mathrm{H} 4 \mathrm{a}$ and $\mathrm{H} 4 \mathrm{~b}$, but only with respect to spillovers originating from parental technology flows. Taken together, these results suggest that the basis for any spillovers arising from MNE affiliates does not originate from codified knowledge associated with $R \& D$, but rather from the productivity of the affiliate. Note, however, that both of these effects derive ultimately from the parent company (i.e. exploitation with spillovers), not from the affiliates' own investment in R\&D or knowledge capital.

Second, the better performing affiliates in terms of profitability exploit technology from the parent, but do not transfer it to local firms. This suggests, in line with intuition, that those affiliates best able to prevent the leakage to local firms of proprietary and non-proprietary knowledge transferred from the parent company are in turn the most profitable.

There are also significant country of ownership effects. Affiliates from all three countries show evidence of being involved in knowledge exploiting transfers (i.e. from parent to affiliate) accompanied by spillovers to the domestic economy.

However, US affiliates are also positively associated with spillovers in the absence of knowledge transfer from the parents, which is absent in the case of EU and (especially) Japanese affiliates.

Note that although the industry and country dummies display significant coefficients in several cases in both Tables 4 and 5, in both cases the 'core' independent variables provide the bulk of the explanatory power (Table 6$)^{7}$.

(Table 6 about here)

\section{Conclusions}

Most empirical evidence on international technology transfer comes from an indirect methodology, often inferring intra-firm technology flows from a statistical relationship between foreign presence and productivity in the host country. Using a unique data set, we are able to identify technology flows within firms, and from inward investors to local firms, and to link these to affiliate characteristics. From a policy point of view the strength of the analysis lies in helping to establish exactly which types of affiliates are most likely to generate beneficial spillovers, and so help host governments in deciding which ones to support in policy terms.

Within the confines of a cross-sectional dataset, the pattern of results may help in telling us something about the ambiguities and lack of consistency found in many spillover studies. For example, the results of the survey of Italian affiliates make it clear that affiliate-level investment in R\&D and knowledge capital markedly affects their capacity to engage in two-way and reverse technology transfer to their parents,

\footnotetext{
${ }^{7}$ Estimations for only the manufacturing affiliates in the sample show little difference from those for the full sample in terms of coefficient signs or significance. These estimations are available from the authors on request.
} 
but does not necessarily enhance their capacity to self-generate knowledge externalities. It is also evident that the source of knowledge spillovers deriving from MNEs in Italy is not codified knowledge or technology associated with R\&D, but rather with the superior productivity of their affiliates. Finally, profitable affiliates are those best able to prevent the leakage to local firms of proprietary and non-proprietary technology transferred from the parent company. 
Figure 1: Matrix of intra-group knowledge transfer

\begin{tabular}{|c|c|c|c|}
\hline & & Transfer fror & liate to Parent \\
\hline & & Yes & No \\
\hline $\begin{array}{l}\text { Transfer } \\
\text { from } \\
\text { Parent }\end{array}$ & Yes & $\begin{array}{c}\text { (1) } \\
\text { Two-way transfer }\end{array}$ & $\begin{array}{l}(2) \\
\text { Knowledge exploiting } \\
\text { transfer }\end{array}$ \\
\hline Afflllate & No & $\begin{array}{l}\text { (3) } \\
\text { Knowledge sourcing } \\
\text { transfer }\end{array}$ & $\begin{array}{c}(4) \\
\text { No knowledge transfer }\end{array}$ \\
\hline
\end{tabular}

Figure 2: Matrix of affiliate-domestic knowledge transfer and spillovers

Transfer from Affiliate to Domestic Firms

\begin{tabular}{|c|c|c|c|}
\hline & & Yes & No \\
\hline $\begin{array}{l}\text { Transfer } \\
\text { from } \\
\text { Parent }\end{array}$ & Yes & $\begin{array}{l}\text { (1) } \\
\text { Knowledge exploiting } \\
\text { with spillovers }\end{array}$ & $\begin{array}{l}\text { (2) } \\
\text { Knowledge exploiting } \\
\text { without spillovers }\end{array}$ \\
\hline Affiliate & No & $\begin{array}{l}\text { (3) } \\
\text { Spillovers from affiliate } \\
\text { only }\end{array}$ & $\begin{array}{l}(4) \\
\text { No knowledge transfer or } \\
\text { spillovers }\end{array}$ \\
\hline
\end{tabular}


Table 1: Sample distribution by activity of the foreign affiliates

$\begin{array}{llrr}\begin{array}{l}\text { Industry } \\ \text { code }\end{array} & \text { Description of the industry } & \text { No. } & \text { Percent } \\ \text { HTI } & \text { High technology industries } & 106 & 11.5 \\ \text { MHTI } & \text { Medium-high technology industries } & 352 & 38.2 \\ \text { MLTI } & \text { Medium-low technology industries } & 196 & 21.3 \\ \text { LTI } & \text { Low technology industries } & 146 & 15.9 \\ \text { HTKIS } & \text { Knowledge intensive high technology services } & 121 & 13.1 \\ \text { Total } & & \mathbf{9 2 1} & \mathbf{1 0 0 . 0}\end{array}$

Note: Based on the classification of high-technology industries and knowledgeintensive services jointly developed by OECD-EUROSTAT

Table 2: Continuous and discrete variables for the Italian foreign affiliates

\begin{tabular}{|c|c|c|}
\hline Variables & Data source & Description \\
\hline \multicolumn{3}{|c|}{ Continuous variables } \\
\hline $\begin{array}{l}\text { Turnover, Employees, Value added, } \\
\text { Labour costs, Stock of tangible and } \\
\text { intangible fixed investments }\end{array}$ & $\begin{array}{l}\text { Surveys on company } \\
\text { economic accounts or } \\
\text { Balance sheets - } \\
\text { Administrative data }\end{array}$ & $\begin{array}{l}\text { Size, Size squared, Profitability, } \\
\text { TFP and Tangible and intangible } \\
\text { fixed assets }\end{array}$ \\
\hline Exports & $\begin{array}{l}\text { Surveys on foreign } \\
\text { trade in goods }\end{array}$ & Exports \\
\hline $\begin{array}{l}\text { Research and development } \\
\text { expenditure }\end{array}$ & Survey on R\&D & $\mathrm{R} \& \mathrm{D}$ \\
\hline \multicolumn{3}{|c|}{ Discrete variables } \\
\hline $\begin{array}{l}\text { Inward technological transfer from the } \\
\text { parent company to the foreign affiliate }\end{array}$ & $\begin{array}{l}\text { Survey on foreign } \\
\text { affiliates in Italy }\end{array}$ & See description in text. \\
\hline \multicolumn{3}{|l|}{$\begin{array}{l}\text { Outward technological transfer from the } \\
\text { foreign affiliate to the parent company }\end{array}$} \\
\hline $\begin{array}{l}\text { Knowledge diffusion (Spillovers) from } \\
\text { foreign affiliate toward local companies }\end{array}$ & & \\
\hline
\end{tabular}


Table 3: Correlation matrix

\begin{tabular}{lccccccc} 
& \multicolumn{2}{c}{$\begin{array}{l}\text { Tangible } \\
\text { fixed }\end{array}$} & $\begin{array}{l}\text { Intangible } \\
\text { fixed }\end{array}$ & & & & \\
Variables & Size & assets & assets & R\&D & Exports & TFP & Profitability \\
Size & 1.00 & & & & & & \\
Tangible fixed assets & 0.31 & 1.00 & & & & & \\
Intangible fixed assets & 0.06 & 0.21 & 1.00 & & & & \\
R\&D & 0.08 & 0.03 & 0.03 & 1.00 & & & \\
Exports & 0.23 & 0.20 & 0.00 & -0.02 & 1.00 & & \\
TFP & 0.00 & 0.01 & 0.13 & 0.03 & -0.12 & 1.00 & \\
Profitability & -0.26 & 0.00 & 0.09 & 0.02 & -0.07 & 0.27 & 1.00
\end{tabular}


Table 4: Multinomial logit estimates for intra-group transfer of technology

\begin{tabular}{|c|c|c|c|}
\hline Variables & $\begin{array}{c}\text { Two-way transfer } \\
\text { (Q.1) }\end{array}$ & Exploiting (Q.2) & Sourcing (Q.3) \\
\hline Size & $\begin{array}{c}-0.63 \\
(-0.51)\end{array}$ & $\begin{array}{c}-1.6 \\
(-1.27)\end{array}$ & $\begin{array}{c}-8.57 \\
(-1.08)\end{array}$ \\
\hline Size squared & $\begin{array}{l}0.43 \\
(0.72)\end{array}$ & $\begin{array}{c}0.80 \\
(1.34)\end{array}$ & $\begin{array}{c}4.39 \\
(1.11)\end{array}$ \\
\hline Tangible fixed assets & $\begin{array}{c}0.18 \\
(2.24)^{\star *}\end{array}$ & $\begin{array}{l}0.07 \\
(0.88)\end{array}$ & $\begin{array}{l}-0.30 \\
(-1.49)\end{array}$ \\
\hline Intangible fixed assets & $\begin{array}{l}-0.08 \\
(-1.30)\end{array}$ & $\begin{array}{c}-0.11 \\
(-1.85)^{\star}\end{array}$ & $\begin{array}{c}0.24 \\
(2.24)^{\star \star}\end{array}$ \\
\hline R\&D & $\begin{array}{c}13.6 \\
(2.58)^{\star \star \star}\end{array}$ & $\begin{array}{l}-36.79 \\
(-2.39)^{\star \star}\end{array}$ & $\begin{array}{c}16.68 \\
(3.10)^{\star \star \star}\end{array}$ \\
\hline Exports & $\begin{array}{c}0.16 \\
(0.53)\end{array}$ & $\begin{array}{c}-0.60 \\
(-1.89)^{\star}\end{array}$ & $\begin{array}{c}1.20 \\
(2.36)^{\star \star}\end{array}$ \\
\hline TFP & $\begin{array}{l}0.09 \\
(0.50)\end{array}$ & $\begin{array}{c}0.15 \\
(0.87)\end{array}$ & $\begin{array}{c}-0.82 \\
(-2.18)^{\star \star}\end{array}$ \\
\hline Profitability & $\begin{array}{l}-0.49 \\
(-0.64)\end{array}$ & $\begin{array}{l}-0.17 \\
(-0.28)\end{array}$ & $\begin{array}{c}2.22 \\
(1.52)\end{array}$ \\
\hline Industry-Country dummie & & & \\
\hline $\mathrm{HTI}$ & $\begin{array}{c}0.86 \\
(2.47)^{\star \star \star}\end{array}$ & $\begin{array}{c}0.83 \\
(2.39)^{\star \star}\end{array}$ & $\begin{array}{c}1.35 \\
(1.75)^{\star}\end{array}$ \\
\hline MHTI & $\begin{array}{c}0.74 \\
(2.80)^{\star \star \star}\end{array}$ & $\begin{array}{c}0.58 \\
(2.17)^{\star \star}\end{array}$ & $\begin{array}{c}1.32 \\
(2.05)^{\star \star}\end{array}$ \\
\hline MLTI & $\begin{array}{c}0.43 \\
(1.48)\end{array}$ & $\begin{array}{c}0.33 \\
(1.14)\end{array}$ & $\begin{array}{c}1.71 \\
(2.53)^{\star \star \star}\end{array}$ \\
\hline HTKIS & $\begin{array}{c}1.11 \\
(3.15)^{\star \star \star}\end{array}$ & $\begin{array}{c}0.68 \\
(2.01)^{\star \star}\end{array}$ & $\begin{array}{c}0.70 \\
(0.61)\end{array}$ \\
\hline US & $\begin{array}{c}0.73 \\
(2.41)^{\star \star}\end{array}$ & $\begin{array}{c}0.40 \\
(1.39)\end{array}$ & $\begin{array}{l}-0.35 \\
(-0.65)\end{array}$ \\
\hline EU & $\begin{array}{c}0.89 \\
(3.32)^{\star \star \star}\end{array}$ & $\begin{array}{c}0.31 \\
(1.25)\end{array}$ & $\begin{array}{c}0.44 \\
(1.02)\end{array}$ \\
\hline $\begin{array}{l}\text { Japan } \\
\text { Constant }\end{array}$ & $\begin{array}{c}1.28 \\
(2.14)^{\star \star} \\
-3.28 \\
(-6.01)^{\star \star \star}\end{array}$ & $\begin{array}{c}1.49 \\
(2.72)^{\star \star \star} \\
-1.11 \\
(-2.11)^{\star \star}\end{array}$ & $\begin{array}{c}-32.79 \\
(-52.28)^{\star \star \star} \\
-4.38 \\
(-4.11)^{\star \star \star}\end{array}$ \\
\hline Number of observations & 921 & & \\
\hline $\begin{array}{l}\text { Shares of companies in } \\
\text { each quadrant }\end{array}$ & 0.30 & 0.24 & 0.06 \\
\hline Log pseudo-likelihood & -1038.19 & & \\
\hline Wald Chi $^{2}(45)$ & 10760.81 & & \\
\hline Prob > Chi ${ }^{2}$ & 0.00 & & \\
\hline Pseudo $\mathrm{R}^{2}$ & 0.09 & & \\
\hline
\end{tabular}

Notes: $*, * *, * * *$ significant at the $10 \%, 5 \%$ and $1 \%$ level respectively 
Table 5: Multinomial logit estimates for affiliate-domestic transfer of knowledge

\begin{tabular}{|c|c|c|c|}
\hline Variables & $\begin{array}{l}\text { Exploitation with } \\
\text { spillovers (Q.1) }\end{array}$ & $\begin{array}{l}\text { Exploitation with no } \\
\text { spillovers (Q.2) }\end{array}$ & $\begin{array}{c}\text { Spillovers from affiliates } \\
\text { only (Q.3) }\end{array}$ \\
\hline Size & $\begin{array}{c}-1.83 \\
(-1.66)^{\star}\end{array}$ & $\begin{array}{c}-0.64 \\
(-0.52)\end{array}$ & $\begin{array}{c}-0.37 \\
(-0.20)\end{array}$ \\
\hline Size squared & $\begin{array}{l}0.98 \\
(1.84)^{*}\end{array}$ & $\begin{array}{l}0.34 \\
(0.58)\end{array}$ & $\begin{array}{l}0.23 \\
(0.26)\end{array}$ \\
\hline Tangible fixed assets & $\begin{array}{l}-0.017 \\
(-0.22)\end{array}$ & $\begin{array}{c}0.14 \\
(1.57)\end{array}$ & $\begin{array}{l}-0.10 \\
(-0.68)\end{array}$ \\
\hline Intangible fixed assets & $\begin{array}{l}-0.072 \\
(-1.30)\end{array}$ & $\begin{array}{l}-0.10 \\
(-1.47)\end{array}$ & $\begin{array}{l}-0.08 \\
(-0.76)\end{array}$ \\
\hline R\&D & $\begin{array}{c}-1.94 \\
(-1.81)^{\star *}\end{array}$ & $\begin{array}{l}-1.64 \\
(-1.23)\end{array}$ & $\begin{array}{l}-8.63 \\
(-1.02)\end{array}$ \\
\hline Exports & $\begin{array}{c}0.02 \\
(0.05)\end{array}$ & $\begin{array}{c}1.00 \\
(3.07)^{\star \star \star}\end{array}$ & $\begin{array}{l}0.58 \\
(1.14)\end{array}$ \\
\hline TFP & $\begin{array}{c}0.28 \\
(1.71)^{\star \star}\end{array}$ & $\begin{array}{c}0.12 \\
(0.60)\end{array}$ & $\begin{array}{l}-0.06 \\
(-0.21)\end{array}$ \\
\hline Profitability & $\begin{array}{l}0.35 \\
(0.62)\end{array}$ & $\begin{array}{c}1.29 \\
(2.02)^{\star \star}\end{array}$ & $\begin{array}{l}0.71 \\
(1.07)\end{array}$ \\
\hline Industry-Country dummies & & & \\
\hline 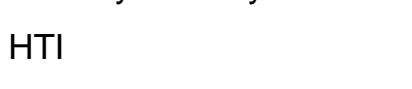 & $\begin{array}{c}0.93 \\
(2.71)^{\star \star \star}\end{array}$ & $\begin{array}{c}0.88 \\
(2.18)^{\star \star}\end{array}$ & $\begin{array}{c}0.02 \\
(0.03)\end{array}$ \\
\hline MHTI & $\begin{array}{c}0.57 \\
(2.33)^{\star \star}\end{array}$ & $\begin{array}{c}0.41 \\
(1.45)\end{array}$ & $\begin{array}{l}0.58 \\
(1.27)\end{array}$ \\
\hline MLTI & $\begin{array}{c}0.62 \\
(2.34)^{\star \star}\end{array}$ & $\begin{array}{c}0.44 \\
(1.39)\end{array}$ & $\begin{array}{c}0.60 \\
(1.10)\end{array}$ \\
\hline HTKIS & $\begin{array}{c}1.56 \\
(4.27)^{\star \star \star}\end{array}$ & $\begin{array}{c}1.41 \\
(3.28)^{\star \star \star}\end{array}$ & $\begin{array}{l}1.36 \\
(2.16)\end{array}$ \\
\hline US & $\begin{array}{c}0.87 \\
(3.19)^{\star \star \star}\end{array}$ & $\begin{array}{c}0.31 \\
(0.97)\end{array}$ & $\begin{array}{c}0.94 \\
(1.86)^{\star}\end{array}$ \\
\hline EU & $\begin{array}{c}0.78 \\
(3.42)^{\star \star \star}\end{array}$ & $\begin{array}{c}0.61 \\
(2.33)^{\star \star}\end{array}$ & $\begin{array}{c}0.71 \\
(1.50)\end{array}$ \\
\hline Japan & $\begin{array}{c}1.53 \\
(2.76)^{\star \star \star}\end{array}$ & $\begin{array}{c}0.74 \\
(1.10)\end{array}$ & $\begin{array}{c}-28.00 \\
(-42.28)^{\star \star \star}\end{array}$ \\
\hline Constant & $\begin{array}{c}-1.01 \\
(-2.08)^{\star \star}\end{array}$ & $\begin{array}{c}-2.11 \\
(-3.73)^{\star \star \star}\end{array}$ & $\begin{array}{c}-2.78 \\
(-2.97)^{\star \star \star}\end{array}$ \\
\hline Number of observations & 921 & & \\
\hline $\begin{array}{l}\text { Shares of companies in } \\
\text { each quadrant }\end{array}$ & 0.48 & 0.21 & 0.06 \\
\hline Log pseudo-likelihood & -1042.06 & & \\
\hline Wald $\mathrm{Chi}^{2}(45)$ & 13418.67 & & \\
\hline Prob $>\mathrm{chi}^{2}$ & 0.00 & & \\
\hline Pseudo $\mathrm{R}^{2}$ & 0.05 & & \\
\hline
\end{tabular}

Notes: $*, * *, * * *$ significant at the $10 \%, 5 \%$ and $1 \%$ level respectively 
Table 6: Pseudo $R^{2}$ values for estimations in Tables 4 and 5

\begin{tabular}{|l|l|l|}
\hline Model specification & Table 4 & Table 5 \\
\hline Full model (explanatory variables with industry and country dummies) & 0.0911 & 0.0505 \\
\hline Explanatory variables only & 0.0673 & 0.0258 \\
\hline Industry and country dummies only & 0.0251 & 0.0256 \\
\hline Industry dummies only & 0.0136 & 0.0134 \\
\hline
\end{tabular}




\section{References}

Andersson U, Forsgren M, \& Holm U. 2007. Balancing subsidiary influence in the federative MNC: a business network view. Journal of International Business Studies, 38: $802-818$

Andersson U, Forsgren M, \& Holm U. 2001. Subsidiary Embeddedness and Competence Development in MNCs - A Multi-Level Analysis. Organization Studies, 22: 1013-1034.

Andersson U, Bjorkman I \& Forsgren M. 2005. Managing subsidiary knowledge creation: The effect of control mechanisms on subsidiary local embeddedness. International Business Review, 14: 521-538

Bell M \& Marin A. 2004. Where do foreign direct investment-related technology spillovers come from in emerging economies? An exploration of Argentina in the 1990s. European Journal of Development Research, 16: 653-686.

Blomström, M. \& Kokko, A. 1998. Multinational Corporations and Spillovers. Journal of Economic Surveys, 12: 247-77.

Caves, R. 1996. Multinational Enterprise and Economic Analysis. Cambridge: Cambridge University Press.

Cohen W M \& Levinthal D A. 1989. Innovation and learning: the two faces of R\&D. Economic Journal, 99: 569-596.

Driffield, N. 2001. The impact on domestic productivity of inward investment in the UK. The Manchester School, 69:103-119.

Driffield N \& Love J H. 2007. Linking FDI Motivation and Host Economy Productivity Effects: Conceptual and Empirical Analysis. Journal of International Business Studies, 38: 460-473.

Ito B \& Wakasugi R. 2007. What factors determine the mode of overseas R\&D by multinationals? Empirical evidence. Research Policy, 36: 1275-1287.

Haskel J, Pereira J E, Slaughter S C \& Matthew J. 2007. Does Inward Foreign Direct Investment Boost the Productivity of Domestic Firms. Review of Economics and Statistics, 89: 482-496.

Marin A \& Bell M. 2006. Technology spillovers from foreign direct investment (FDI): the active role of MNC subsidiaries in Argentina in the 1990s. Journal of Development Studies, 42: 678-697.

Oulton, N. 1997. Total Factor Productivity Growth and the Role of Externalities. National Institute Economic Review. 162: 99-111.

Serapio M G \& Dalton D H. 1999. Globalization of industrial R\&D: an examination of foreign direct investments in R\&D in the United States. Research Policy, 28: 303316. 
Veugelers R \& Cassiman B. 2004. Foreign subsidiaries as a channel of international technology diffusion: some direct firm level evidence from Belgium. European Economic Review, 48: 455-476.

Wagner J. 2007. Exports and productivity: a survey of the evidence from firm-level data. The World Economy, 30: 60-82.

Wei Y \& Liu X. 2006. Productivity spillovers from R\&D, exports and FDI in China's manufacturing sector. Journal of International Business Studies, 37: 544-557. 
Annex

\section{STATISTICAL SURVEY ON FOREIGN AFFILIATES RESIDENT IN \\ ITALY 2003-2004}

\section{SECTION 5 - OTHER INFORMATION ON FOREIGN AFFILIATES}

5.1 Are the relationships between the company and the companies resident abroad but belonging to the same international enterprise group (parent company or foreign resident affiliates of the same MNE) significantly characterised by one or more of the following aspects?

\begin{tabular}{|l|l|c|l|c|}
\hline & \multicolumn{2}{|c|}{ From the company to abroad (1) } & \multicolumn{2}{|l|}{ From abroad to the company (2) } \\
\hline $\begin{array}{l}\text { A. Transfer of scientific and } \\
\text { technological knowledge }\end{array}$ & Yes $\square 1$ & No $\square 2$ & Yes $\square 1$ & No $\square 2$ \\
\hline $\begin{array}{l}\text { B. Transfer of managerial, commercial } \\
\text { competencies or other types of business } \\
\text { expertise }\end{array}$ & Yes $\square 1$ & No $\square 2$ & Yes $\square 1$ & No $\square 2$ \\
\hline
\end{tabular}

5.2 Has the foreign control affected the relationships between the company and the other companies active on the national territory in any of the following ways?
A. Increase in the competition in the final goods market
yes $\square 1 \quad$ no $\square 2$
B. Increase in the demand for intermediate or instrumental products
yes $\square 1$
no $\square 2$
C. Diffusion of new knowledge or other know-how
yes $\square 1$
no $\square 2$

\section{DEFINITIONS FOR COMPILING THE QUESTIONNAIRE}

Transfers of scientific and technological know-how: they refer to all the exchanges of scientific and technological expertise and know-how between the company and the companies resident abroad but belonging to the same international group. These transfers can be either material (highly-technological intermediate or instrumental products) or immaterial (use of patents, licences, software or collaborations in research and innovation activities)

Transfers of managerial, commercial competencies or other type of expertise: they refer to the exchanges of expertise and know-how that are not scientific nor technological between the company and the companies resident abroad but belonging to the same international group. These transfers may determine the adoption of new procedures or standards in the company's general organization or only in some specific areas of it: commercial, administrative, logistics, etc. 